\title{
Credit Fraud as One of the Dimensions in the Banking Crime
}

\author{
(In a White-Collar Crime Perspective)
}

\author{
Ida Nurhayati*, Indianik Aminah \\ State Polytechnic of Jakarta \\ Jakarta, Indonesia \\ *ida.nurhayati@akuntansi.pnj.ac.id, indianik.aminah@akuntansi.pnj.ac.id
}

\begin{abstract}
This study aims to describe and understand if fraud on banks could be categorized as a white-collar crime. Fraud in banking is found in the majority of bank workers, who are assisted by third parties. This study employs descriptive qualitative research methods through a formal juridical approach, review of banking regulations, and FGDs involving the police, banking experts, and fraud perpetrators. Our result found out that the prevailed credit fraud was a dominant part of banking crime. Data above shows that the most significant fraud/fraud in the credit sector, which reaches 5 percent, indicates that credit is still a part that can encourage someone or several people to commit fraud. Therefore, we obtained a pattern/modus operandi of credit fraud that could be categorized as one of the dimensions of crime in the banking sector and white-collar crime. The result will be an alternative material to prevent credit crime in banks.
\end{abstract}

Keywords -credit fraud, banking crime, white-collar crime

\section{INTRODUCTION}

Credit is the banks' primary business activity, especially in carrying out its function as a bank that collects and distributes public funds. Because as part of the primary business activities, then, in its implementation, it becomes crucial, especially in banking business activities, and therefore prone to irregularities.

The relationship between the bank and its customers, both depositors and users of credit, is a contractual relationship. It has become a consequence for banks to carry out business activities in collecting and distributing them. The customer relationship with the bank is based on contractual law as in Article 1320 of the Civil Code to the public to be carried out cautiously, carefully, thoroughly, and wisely by minimizing the possibility of risks. Mulyati. [1]. Credit provided by banks carries many risks. Hence, in its implementation, banks must pay attention to the credit principles, by applying the principle of prudence and reducing the risk of violations, since the bad credit rating is the consequence.

Sutherland [2] explained that professional thieves have many characteristics that are very similar to those that are unprofessional. Professional people are careful in making plans for the success of their activities. The thief also carefully plans every action, including the determination of the case if he is arrested.

Violations and crime in banking, including criminology. (the study of crime, perpetrators of crime, victims of crime, and prevention of crime) including white-collar crime. Whitecollar crime violates trust because it creates distrust, lowers social morale, and results in large-scale social disorganization. Thus, violations of the banker's profession code of ethics are in violations of banking crimes in lawful work.

TABLE I. CASE OF FrAUD IN BANKING 2014-2016

\begin{tabular}{|l|l|l|}
\hline No & \multicolumn{1}{|c|}{ Type of Case } & Percentage (\%) \\
\hline 1 & Credit & 55 \\
\hline 2 & Fund Disbursement Manipulation & 21 \\
\hline 3 & Embezzlement & 15 \\
\hline 4 & Transfer of Funds & 5 \\
\hline 5 & Asset Procurement & 4 \\
\hline
\end{tabular}

Table 1 illustrates that from several banking crimes, the largest percentage is shown in credit fraud violations.

The research question of this study is why does credit fraud dominate banking crimes? Furthermore, how are the pattern and modus operandi of fraud in credit?

\section{LITERATURE REVIEW}

Tampubolon [3] referred to by Kennedy et al. [4] Acts of fraud can be said to be criminal if the intention or act of obtaining a dishonest profit also violates legal provisions, such as corruption or tax evasion.

The Financial Services Authority (OJK) noted 108 cases of banking crime for almost two years (2014-2016). The most types of fraud cases in banking are credit cases, including credit card data, credit card data theft, incorrect recording, and others. The Chief Executive of Banking Supervision in the OJK Board of Commissioners member, Nelson Tampubolon [3] in the Socialization of Handling of Alleged Banking Crimes and Anti-Fraud Forum, said that banking operations 
have a high complexity of irregularities, both administratively and leading to criminal acts or fraud.

Tillman [5] analysis shows a network of collusion and financial statements related to most board members, auditors, and bankers who assist and conspire with senior managers in their efforts to find investors.

Cohen et al. [6] found that personality traits appear to be a significant risk factor for fraud. Manuela Pulina, Antonello Paba [7] analyzes that specific socio-economic and banking demographics that influence fraud risk in a portfolio are credit cards.

Credit crime is the fastest way to drain funds in the bank by bank owners Siahaan. [8] Concerning banking crimes, the community's losses are enormous because they take advantage of the situation. That condition makes the customer lose the deposited funds; then, it will impact losing the customer's trust in the bank The condition of the victim (or customer) who has trusted him, and it is related to his position [9].

\section{A. Dimensions of Banking Crime}

There are several dimensions of banking crime: (1). a person's crime against a bank, (2). a bank crime against another bank, or (3). a bank crime against an individual. The banking crime space dimension is not limited to a particular place but can be across country territorial boundaries. Likewise, the dimension of time can occur instantaneously, but also be able to take a few moments. Qualifications of banking crimes. Djumhana [10] that often occur, including:

- Credit fraud

- Embezzlement of public funds

- Misappropriation of public funds

- Violation of currency regulation

The pattern of banking crimes is often complicated because the culprit is the person who is an expert in his field and also usually very neat and veiled e.g., have disguising intent or intention. Hence, banking crimes are classified as white-collar crime.

Muladi provided identification of white-collar crime which includes:

- Disguises or the hidden nature of the intent and purpose of crime.

- The perpetrator's confidence in the victim's ignorance and carelessness., in this case, the perpetrator benefice from the victim's the lack of expertise and knowledge.

- Concealment of the violation.

Also, the characteristic of white-collar crime is the crime based on the misuse of public trust. Therefore, the most common white-collar crimes occur in public trust institutions, such as banks, stock exchanges, insurance companies (Muladi). Often in these crimes, there is a tendency for collusion between the perpetrators with the businessmen and authorities. In contrast to conventional crime, white-collar crime can only be identified after a lapse of time, whereas a conventional crime is visible and can be immediately known [10].

\section{B. Banking Crime as One of White-Collar Crime}

Crimes, violations or fraud in the banking sector, committed by bankers as individuals as well as the bank itself as a corporation, can both mean that bankers as individuals and at the same time banking institutions become one in crime, through banking policy be categorized as white-collar crimes because the characteristics of these white-collar crimes can be found on there, revise this sentence, it has low structure.

Several studies have proposed predictive models for credit card fraud detection based on different machine learning techniques. Sadgali, et al. [11] White-collar crime consists of several distinct components [12]:

1) Fraud: people involved in white-collar crime tend to deceive, lie, hide, and manipulate the truth.

2) Intentional: fraud is not the result of simple mistakes or negligence but involves efforts aimed at obtaining illegal profits. Thus, it induces an action that has been predetermined by the offender.

3) Trust Violation: business is based primarily on trust personal relationships and commitments direct to all parties' respective responsibilities of all parties. Mutual trust is the glue that binds these relationships together, and this is a trust that is broke when someone tries to deceive another person or business.

4) Involve losses: financial crime based on trying to get profit and illegal security, and for this to happen, there must be victims. Therefore, every business transaction, contract, payment, or agreement can be changed or pressed to provide order.

5) Beyond the honorable appearance, fraud can be committed by people who appear to be respectable and professional members of the community and can even be used by victims.

\section{Credit Crime}

This crime is usually committed by people who already understand the ins and outs of banking and its operations. Included in this crime is fictitious credit. These crimes can be characterized by window dressing (reports to Bank Indonesia are manipulate), manipulation of tax reports, not recording a loan portfolio, manipulation of credit that does not exist, and although there is exceeding the maximum credit limit (plundering). Victims of this fictitious credit are banks. This case is the fastest way done by bank owners to drain funds in the bank [8].

The previous study still discussed financial fraud committed by banks and the penalties applied by the Court were still mostly general criminal penalties, which are still comparable to conventional crimes. Whereas if the perpetrator is a banker, moreover it is carried out on a state bank, then it has entered into a particular criminal law, in this case, it is corruption, and has become part of the white-collar crime. The author strongly agrees that in Indonesia, the application of punishment to the perpetrators of corruption in the banking 
system, the applied regulation is the Corruption Act. Because there have been many customers harmed by the abuse of authority and position associated with their legal work, this is according to Sutherland's white-collar crime theory (1939).

\section{RESEARCH METHODS}

This study using a descriptive qualitative method through a normative juridical approach, legal and formal aspects, and the examination process took from the Report of Investigation by the authorities. However, in this case, especially at the policy level, it cannot be disclosed, the researcher has given by oral exposure by the offender in prison.

The next step was carried out FGDs with the authorities involved in inspection and administration, up to the investigation at the police level. FGDs analyzed the legal and theoretical basis associated with research. The banking sector experts and financial authorities formulated an initial concept that will be input for management to overcome fraud, especially credit in banking.

The place of this research conduct in several banks such as commercial banks and state banks in Jakarta and Surabaya. Both cities represent places where the perpetrators of fraud have been sentenced to prison by the Court.

The analysis technique used is a qualitative method, using a formal juridical approach, by analyzing Report of Investigation from the authorities, in this case, investigators from the Police and Financial Services Authority (OJK). The results were confirmed by the perpetrators and investigators using the WCC. White-Collar Crime is a theory put forward by Sutherland [2] that professional thieves can be committed by those who have high social status, are educated, and are carried out in connection with legitimate work. This refers to credit fraud perpetrators. Legitimate work is misused by using position and authority in the work. Monster Grid is a research method used by Hubbert [13] on corruption in government institutions in the Netherlands. Hubbert took a sample of corruptors connected with special relationships, lifestyles, and others. The model is the author applied in this study, but the sample is taken from the perpetrators of corruption in banking to be able to produce a pattern or mode of credit crime on banks. The Monster Grid method has collaborated with the Cilnard-Quinney method. The result will be as an alternative material to prevent credit crime in banks. The author also collecting regulatory documents as secondary data sources related to banking, regulations related to banking, which are confirmed by data from interviews with competent and authorized parties.

\section{RESUlTS AND DISCUSSION}

The results of interviews with the Financial Services Authority (OJK) and bankers at the management level related to regulations, implementation, and the targets made by decision-makers, both at the middle management level and supervisors, in this case, Financial Services Authority (OJK).

From these data, researchers have identified the data found in the field as a result of interviews and FGDs with the Police and Banking as follows (table 2):
TABLE II. RESULT OF INTERVIEW AND FOCUS GROUP DISCUSSIONS

\begin{tabular}{|c|c|c|}
\hline No & Questions & Answers \\
\hline 1 & $\begin{array}{l}\text { Are there always } \\
\text { Standardized } \\
\text { Operating } \\
\text { Procedures in the } \\
\text { bank operational? }\end{array}$ & Yes, there are. \\
\hline 2 & $\begin{array}{l}\text { Beside SOPs, are } \\
\text { there any } \\
\text { references in the } \\
\text { bank operational? }\end{array}$ & $\begin{array}{l}\text { Company Law or Banking Law and all } \\
\text { regulations set by Central Bank (BI) and } \\
\text { Financial Services Authority (OJK) }\end{array}$ \\
\hline 3 & $\begin{array}{l}\text { How are SOPs } \\
\text { implemented and } \\
\text { evaluated? }\end{array}$ & $\begin{array}{l}\text { In some parts, it still cannot be implemented } \\
\text { properly, there are still violations. } \\
\text { Evaluated in the part where many violations } \\
\text { occur. }\end{array}$ \\
\hline 4 & $\begin{array}{l}\text { How is the modus } \\
\text { operandi of credit } \\
\text { fraud? }\end{array}$ & $\begin{array}{l}\text { There are some modus operandi that happen, } \\
\text { mostly are fictitious credits. } \\
\text { They are followed by the markup value of } \\
\text { the guarantee. Everything aims to take bank } \\
\text { money for personal gain. } \\
\text { Collaboration with parties outside the bank, } \\
\text { which served to accommodate the proceeds } \\
\text { of fraud. } \\
\text { Even the outside parties also play a crucial } \\
\text { role overseas. }\end{array}$ \\
\hline 5 & $\begin{array}{l}\text { What can be done } \\
\text { by the bank to the } \\
\text { perpetrator? }\end{array}$ & $\begin{array}{l}\text { Both internal or external actors are reported } \\
\text { to the authorities. }\end{array}$ \\
\hline 6 & $\begin{array}{l}\text { How is the bank } \\
\text { action toward } \\
\text { internal actors? }\end{array}$ & $\begin{array}{l}\text { First, an investigation by compliance } \\
\text { division and forward to legal division if the } \\
\text { result of the inquiry from compliance } \\
\text { division indicates that is any law violation. } \\
\text { Second, if the legal division recommends } \\
\text { proceeding to the authorities in this case, } \\
\text { police, then the case would be processed by } \\
\text { statutory regulations. }\end{array}$ \\
\hline 7 & $\begin{array}{l}\text { If the banker is } \\
\text { legally processed, } \\
\text { how is the } \\
\text { employment } \\
\text { status? }\end{array}$ & $\begin{array}{l}\text { If the violation is severe enough to be very } \\
\text { severe so that the threat of punishment is } \\
\text { also above } 5 \text { (five) years, then the banker is } \\
\text { dismissed as an employee. }\end{array}$ \\
\hline 8 & $\begin{array}{l}\text { Regarding } \\
\text { violations that } \\
\text { commit, if viewed } \\
\text { from Banking } \\
\text { Law, in which } \\
\text { part are the } \\
\text { provisions } \\
\text { violated? }\end{array}$ & $\begin{array}{l}\text { Most of the violations are about banking } \\
\text { secrecy, public fund embezzlement, and } \\
\text { actions that are harmful to the bank. }\end{array}$ \\
\hline 9 & $\begin{array}{l}\text { Beside Banking } \\
\text { Law, are there } \\
\text { any regulations } \\
\text { that violated? }\end{array}$ & $\begin{array}{l}\text { Anti-Money Laundering Law and Anti- } \\
\text { Corruption Law }\end{array}$ \\
\hline 10 & $\begin{array}{l}\text { What is done } \\
\text { internally by the } \\
\text { bank in the } \\
\text { context of the } \\
\text { supervision of the } \\
\text { bank? }\end{array}$ & $\begin{array}{l}\text { - The form of supervision division; } \\
\text { - Applying administrative sanctions if } \\
\text { there is any violation; } \\
\text { - If the violation is severe, it will proceed } \\
\text { to the authorities; } \\
\text { - Practical application of Know Your } \\
\text { Employee principles. }\end{array}$ \\
\hline
\end{tabular}

Source: Primary Data (2019) 
The data above shows that SOPs are already made in operating banks, determined by laws and other banking regulations. For internal supervision, the application is carried out by the supervisory division. While institutionally Bank Indonesia as regulators and the Financial Services Authority, which oversees the banking system.

Violations in the form of fraud on credit become the most frequent because credit is the part that mostly involves outsiders, an opportunity for disbursement, which is used as a modus to drain bank funds. For this purpose, strict and tiered supervision is a need.

Rotation of employees on the part of the credit on an ongoing basis as one of the businesses that are necessary also to break the chain of tyranny that can affect the urge to violate or abuse.

Clinard-Quinney [14], called professional crimes (Professional Criminal Behavior) theoretically as work crimes and professional crimes, as well as parts of white-collar crimes. Crimes in occupation and professional crimes of bankers are in accordance with the status of the perpetrators of the crimes are bankers, especially those who have certain positions (management). Offenders in their jobs and professions usually regard themselves as respectable citizens, not as criminals. Because the perpetrators are in lawful work, it is difficult to imagine that every activity in lawful work can be a crime. These violators define their situation by rationalization, which allows them to be regarded as ordinary violations, which in principle feel not criminal. They think of their behavior only as "an ordinary condition" (Quinney) [15].

\section{CONCLUSION}

Banks as intermediary institutions that receive funds from the public are then converted, appropriately managed - then distributed to the community. One of the distribution is through credit to debtor customers. Credit fraud can occur if managers in their work abuse authority with various crime modes, for example, fictitious credit. Crimes related to legitimate work, as one form of white-collar crime.

\section{ACKNOWLEDGMENT}

Thanks to the Director of the Jakarta State Polytechnic, the Deputy Directors, and the seminar organizing committee.

\section{REFERENCES}

[1] E. Mulyati, Kredit Perbankan (Aspek Hukum Dan Pengembangan Usaha Mikro Kecil Dalam Pembangunan Perekonomian Indonesia). Bandung: PT Refika Aditama. 2016.

[2] E.H. Sutherland, The Professional Thieft. Book Review. Recommended Citation. Locke, Harvey J. (1937) "The Professional Thief, by Edwin H. Suterhland," Indiana Law Journal: Vol. 13: Iss. 2, Article. 1937. p. 13. http://www.repository.law.indiana.edu/ilj/vol13/iss2/13/?utm_source=w ww.repository.law.indiana.edu $\% 2$ Filj\%2Fvol13\%2Fiss2\%2F13\&utm medium=PDF\&utm_campaign=PDFCoverPages. Accessed by 11 July 2015 .

[3] N. Tampubolon, Sejak 2014, OJK Tindak Tegas 108 Kasus Kejahatan Perbankan. CNN Indonesia, Berita Keuangan. [Online] Available at: https://www.cnnindonesia.com/ekonomi/20161114120838-78172491/sejak-2014-ojk-tindak-tegas-108-kasus-kejahatan-perbankan 2016. Accessed 2018, October

[4] J.S.P Kennedy and S.L. Santi, Para Pelaku Fraud Di Indonesia Menurut Survei Fraud Indonesia. | Buletin Ekonomi FE UKI ISSN - 14103842 Vol . 21 No. 2 September 2017. 2017.

[5] R. Tillman, "Reputation And Corporate Malfeasanse: Collusive Networks in Financial Statement Fraud". Journal Crime Law And Social Change. Springer 51(3), pp. 365-382. 2009. https://doi.org/10.1007/s10611-008-9161-1

[6] J. Cohen, et al., "Corporate Fraud And Managers' Behavior: Evidence From The Press". Jounal of Business Ethics. Springers. Vol. 95. 2010. https://www.jstor.org/stable/29789727

[7] M. Pulina and P. Antonello, "A Discrete Choise Approach A Model Credit Card Fraud". Munich Personal RePEc Archive. 2019. https://mpra.ub.uni-muenchen.de/id/eprint/2019.

[8] N.H.T, Siahaan. Pencucian Uang Dan Kejahatan Perbankan. Jakarta Pustaka Sinar Harapan. 2005.

[9] M. Mustofa, Kleptokrasi-Persekongkolan Birokrat-Korporat Sebagai Pola White Collar Crime di Indonesia. Jakarta: Kencana Prenada Media Group. 2010.

[10] M. Djumhana, Hukum Perbankan Di Indonesia. Bandung. PT Citra Aditya Bakti. 1996.

[11] I. Sadgali, et al., "Adaptive Model for Credit Card Fraud Detection". International Journal of Interactive Mobile Technologies. Vol. 14, No. 3.2020.https://www.online-journals.org/index.php/ijim/article/view/11763/6567

[12] P. Gottschalk, "Prevention of White-Collar Crime: The Role of Accounting". Journal of Forensic \& Investigative Accounting. Vol 3 , Iss. 1, pp. 23-48, 2011.

[13] G De Graaf, L.W.J.C. Huberts, "Portraying the Nature of Corruption Using an Explorative Case Study Design". Public Administrationn Review. Vol 68. No. 4. Pp640-653. 2008.

[14] R. Quinney, Richard and C. B Marshal. Criminal Behavior System A Typology. Second Edition. Chapel Hill, Nort Carolina: Madison. 1972. Wisconsin

[15] R. Quinney, White Collar Criminal. The Offender in Business and The Profession-Edited, with introduction and notes, by Gilber Geis-Atherton Press New York. 1968. 